Open Access

\title{
Mediating effect of innovative culture and organizational learning between leadership styles at third-order and organizational performance in Malaysian SMEs
}

\author{
Shafique Ur Rehman ${ }^{1 *}$ (D) Anam Bhatti ${ }^{2}$ and Naveed lqbal Chaudhry ${ }^{3}$
}

* Correspondence:

Shafiqueurrehman2018@gmail.com

'Tunku Puteri Intan Safinaz School of Accountancy, Universiti Utara

Malaysia, Changlun, Malaysia

Full list of author information is available at the end of the article

\begin{abstract}
Purpose: The objective of this study is to see the mediating effect of innovative culture and organizational learning between leadership styles and organizational performance in Malaysian SMEs.
\end{abstract}

Design/methodology/approach: Questionnaires were used to collect data from owners/managers and 950 questionnaires distributed by using postal and email strategy. Out of 950, only 409 questionnaires returned back, 25 questionnaires have missing values and eliminated from a sample, and only 384 questionnaires were used for final analysis.

Findings: Findings reveal that leadership styles have a significant influence on organizational learning, innovative culture, and organizational performance. Innovative culture and organizational learning have a significant influence on organizational performance. Moreover, innovative culture and organizational learning significantly mediate between leadership styles and organizational performance.

Practical implications: In practical term, the current study contributes for managers/ owners in SMEs to focus leadership styles with innovative culture and organizational learning in their decision making if they want to enhance their organizational performance.

Research originality: This study is one of the pioneer studies that test leadership styles at third-order with the combination of two mediating variables innovative culture and organizational learning with organizational performance.

Keywords: Leadership styles, Innovative culture, Organizational learning, Organizational performance

JEL classification: M12, M14, D83, L25 


\section{Introduction}

Effective leadership plays an important role to determine the success or failure of any kind of organization (Tourish, 2014). In the last few decades, leadership is the most studied area in business as well as in industry. Moreover, leadership has become a compulsory part for organizations (Bryman, 2007; Brymer \& Gray, 2006). Despite the wider quantity of studies on leadership, there has been scant research done on small and medium-size enterprises (SMEs) (Franco \& Matos, 2015). A highly competitive market and rapidly changing strategies enhance the importance of leadership in attaining a competitive edge over their competitor through leaders to enhance organizational performance (Jaramillo, Mulki, \& Marshall, 2005). The primary purpose of organizations is to focus financial efficiency but also considers their intangible resources and leadership to maintain competitive advantage (Wang, Chich-Jen, \& Mei-Ling, 2010). Literature demonstrates that Malaysian SMEs faces issues regarding leadership styles that reduce organization performance (Aziz, Abdullah, Tajudin, \& Mahmood, 2013; Hashim, Ahmad, \& Zakaria, 2012; Rahim, Zainal Abidin, Mohtar, \& Ramli, 2015). Prior studies suggested that effective leadership can help to improve the organizational performance in that situation where organizations face a lot of new issues and challenges (Franco \& Matos, 2015; McGrath, Mac Grath, \& MacMillan, 2000). Leadership styles have an influence on both individual and organizational performance (Wang et al., 2010; Windsor, 2009). Sometimes firms do not identify the ineffective or effective leaders until time passed and organizations suffer (Nazarian, Soares, \& Lottermoser, 2017). Leadership styles are a vital element that explains organizational performance. Hence, this study focuses on leadership styles to determine SMEs performance.

Malaysian SMEs faces issues regarding innovative culture and organizational learning (Abdul-Halim, Ahmad, Geare, \& Thurasamy, 2018; Gorondutse \& Hilman, 2018; Hanifah, Halim, Ahmad, \& Vafaei-Zadeh, 2017). Moreover, Malaysian government plans to renovate their economy by adopting innovative culture and organizational learning among SMEs (Abdul-Halim et al., 2018; Hanifah et al., 2017). In addition, most of the articles published on innovation but scant research conducted on innovative culture in respect of SMEs (Abdul-Halim et al., 2018). The motivation behind this study is that Malaysian SMEs performance reduces due to leadership styles, innovative culture, and organizational learning (Abdul-Halim et al., 2018; Rahim, Nik Mahmood, \& Masrom, 2016). This study significantly contributes to the body of knowledge because this is the pioneer study that determines the mediating effect of innovative culture and organizational learning between leadership styles (transactional leadership and transformational leadership) and SMEs performance. In this study, theoretical framework developed with the help of resource-based view (RBV) theory. Leadership styles uses as resources innovative culture and organizational learning uses as capabilities to explain the relationship between resources and organizational performance. This study contribute theoretically because it covers leadership styles (vision, inspirational communication, intellectual stimulation, supportive leadership, personal recognition, contingent rewards, management by exception (active), management by exception (passive), innovative culture, and organizational learning in the light of RBV theory).

Small and medium enterprises (SMEs) play a significant role in the development of an economy and considered as the backbone of Asian countries (Nasir, Al Mamun, \& 
Breen, 2017; Yoshino, Taghizadeh-Hesary, Charoensivakorn, \& Niraula, 2016). In Malaysia, $98.5 \%$ of the business establishment is SMEs and there are 907,065 establishments that contribute $36.6 \%$ of Malaysian's gross domestic product (GDP) in the year 2016 (SMEinfo, 2018). SMEs contribute changes from 2016 to 2020 in terms of GDP ( $36.6 \%$ to $41 \%$ ), employment (65.3\% to $65 \%$ ), and exports ( $18.6 \%$ to 23\%) (SMEinfo, 2018). Therefore, SMEs play an important role in the Malaysian economy. Table 1 elaborates in more details regarding SMEs in Malaysia.

\section{Literature review}

Leadership styles

According to me, "leadership refers to the ability of a person to motivate, influence, and facilitate other persons to contribute to the success of an organization." Moreover, leaders are the persons that facilitate their followers by performing task first then say to others to do this; they eat at the end not at the start; and leaders are those that create opportunities for their followers, society, and for their organization. According to Daft (2014), leadership means a relationship between followers and leaders where both influence each other and lead to revolutionizing and outcomes that reveal their shared objectives. Literature shows that one of the leading typologies of leadership is the Bass's one (Sarti, 2014; Yahaya \& Ebrahim, 2016). Bass (1990) leadership consists of two dimensions such as transformational leadership and transactional leadership. Transformational leadership refers to "a styles of articulating a shared vision of the future, intellectually stimulating subordinates, providing a great deal of support to individuals, recognizing individual differences, and setting high expectation (Kirkman, Chen, Farh, Chen, \& Lowe, 2009). Transformational leadership consists of five dimensions such as articulating a vision, inspirational communication, intellectual stimulation, supportive leadership, and personal recognition as developed (Bass, 1985). Transactional leadership entails an exchange in the relationship between followers and leaders like followers collect prestige and wages for obeying task from leader's side. While transactional leadership consists into three main dimensions like contingent rewards, management exception (active), and

Table 1 SME's information

\begin{tabular}{ll}
\hline Why SMEs matter in Malaysia & \\
\hline Total number of SMEs in Malaysia & 907,065 \\
Contribution to GDP & $36.6 \%$ \\
Micro & $76.5 \%$ \\
Small & $21.2 \%$ \\
Medium & $2.3 \%$ \\
Services & $89.2 \%$ \\
Manufacturing & $5.3 \%$ \\
Construction & $4.3 \%$ \\
Agriculture & $1.1 \%$ \\
Mining and quarrying & $0.1 \%$ \\
\hline Source: (SMEinfo, 2018) &
\end{tabular}


management exception (passive) (Avolio, Bass, \& Zhu, 2004; Bass \& Riggio, 2006; Megheirkouni, Amaugo, \& Jallo, 2018).

\section{Vision}

Vision is recognized as a significant dimension of transformational leadership encompassed by the more common construct of charisma. Bass (1985) give an argument that the most usual and significant part of transformational leadership is called charisma. Leadership with the charisma or idealized influence has superior standards of ethical and moral conduct and can be counted upon to do the right things (Megheirkouni et al., 2018). Charisma refers to the gift of grace or gifted individuals presented by ALLAH and describe individual characteristics that ordinary language generally cannot depict (Levine, Muenchen, \& Brooks, 2010). Moreover, charisma signifies personal attraction that enables an individual to significantly influence other persons (Verčič \& Verčič, 2011). In this study, we are focusing on the term vision that is the opposite a wider construct of charisma influence proposed by Bass and his contemporaries. According to Rafferty and Griffin (2004), vision refers to a transcendent ideal that signifies collective values and ideological in nature. In the current research, we refer the term vision as the expression of an ideal image of upcoming based on firms values.

\section{Inspirational communication}

Inspirational motivation is considered a significant factor of transformational leadership. According to Megheirkouni et al. (2018), leaders that have superior inspirational motivation can communicate higher expectations of their subordinates, inspire subordinates through motivation to become more committed to, and a part of, the joint vision of the firm. Moreover, inspirational communication refers to the team spirit, optimism displayed, and enthusiasm; organizational leaders gets subordinates or followers involved in an attractive vision and commitment to objectives and shared vision features this domain (Yaslioglu \& Erden, 2018). In various ways, inspirational leadership looks alike transformational leadership more deeply as compared to charismatic leadership (Barbuto, 1997). Charismatic leaders refer to a person that focuses on inspiring appeals as well as expressive talks to provoke their follower motivation to go beyond self-centeredness for the good of the group (Bass, 1985). While inspirational leaders boost up the objectives and values of their followers to the firm's goals or missions, then give power to followers to attain them (McClelland, 1975). Although studies have conducted leaders communication but scant research has determined the construct of inspirational communication (Smith, Figgins, Jewiss, \& Kearney, 2018). A frequent part inside inspirational leadership definition is the use of oral announcement or communication to motivate and provoke emotions of followers. Therefore, in this study, we are focusing on inspirational communication to provoke follower's emotions, as contrasting to the wider term of inspirational motivation proposed by Bass and his contemporaries.

\section{Intellectual stimulation}

Intellectual stimulation is an element of transformational leadership that is used less. Intellectual stimulation means a situation where leaders stimulate their followers to be innovative and creative and to challenge their personal values and beliefs (Megheirkouni 
et al., 2018). Moreover, intellectual stimulation refers to a situation where followers are encourage to raise your voice, talk to problem, search solutions, and try new methods (Yaslioglu \& Erden, 2018). The results of intellectual simulations come in terms to enhance the ability of followers to analyze, conceptualize, and comprehend problems and in the superior quality of solutions (Bass \& Avolio, 1990).

\section{Supportive leadership}

Individual consideration is an indicator that distinguishes the transformational leadership with the latest theories regarding leadership. At the start, Bass (1985) recognizes that individual consideration takes place in a situation where a leader has a developmental direction toward followers and exhibited individual consideration to followers and answer properly to their private needs. Supportive leadership requires a significant understanding of the followers needs as well as wants with the purpose of providing them with the essential support (Al-Malki \& Juan, 2018). In order to confirm supportive leadership effectiveness, it is vital for organization leaders to formulate pleasant communication environment with their followers (Al-Malki \& Juan, 2018). Hence, supportive leadership considers a vital part of effective leadership in the path-goal theory. In this study, we define the term supportive leadership as articulating concern regarding followers and work on their personal needs.

\section{Personal recognition}

Personal recognition refers to the rewards from the leader's side in term of congratulating and acknowledgment to their followers for the attainment of particular objectives. According to Rafferty and Griffin (2004), personal recognition means a situation when employees get recognition from leaders for their specified work and due to this, they would feel well within other employees. In addition, personal recognition refers to a follower's acknowledgment due to performing their duties in terms of psychological rewards and admiration (Bass \& Riggio, 2006). Personal recognition means the rewards from leader's side due to achievement of particular objectives (Keskes, 2014). Personal recognition occurs at that time when leader specifies follower's efforts and provides rewards. In this study, we are using personal recognition in term of acknowledgment as well as praise from leader's side for the efforts of followers in attaining organizational objectives.

\section{Contingent rewards}

Contingent rewards refer to "rewards to followers in completing the particular task that the leaders give." According to Podsakoff, Bommer, Podsakoff, and MacKenzie (2006), contingent rewards depict the leader's image that clearly corresponds to the goals to be achieved and that give rewards to followers that fulfill their jobs. Contingent rewards significantly contribute to the team effectiveness as well as team development (Al-Malki \& Juan, 2018). Bass (1985) emphasize that by paying contingent rewards to followers, a transactional leader might encourage a rational level of involvement, commitment, loyalty, and finally performance from subordinates.

\section{Management by exception (active)}

The benefit of management by exception active is that when leaders see any mistake, rule break, failure, and divergence from standards, then leaders take some corrective 
action as rapidly as possible. Management by exception active refers to a leader that examines the findings of followers and reprimands followers that do not meet the standards outcome (Bass \& Riggio, 2006). Active leaders are those persons that respond quickly, not waste time, and take corrective actions as soon as possible. According to Rothfelder, Ottenbacher, and Harrington (2012), it is largely based on taking the corrective actions and leaders control and observe actively their follower's performance, and observe closely for any rules they disobey. Active leaders do not waste time and take initiatives while passive leaders wait until behavior occurs.

\section{Management by exception (passive)}

Management by exception passive is the opposite of management by exception active because in this type of leadership, leaders get involved after a certain problem occurs or when followers do not fulfill the standard outcomes. Management by exception passive has some comments from a leader's side such as criticism, punishment, and not giving rewards that decrease performance. According to Bass and Riggio (2006), management by exception passive refers to a type of leadership where leaders correct the problem when it becomes serious. It refers to contingent punishment (Podsakoff, Todor, Grover, \& Huber, 1984), rectifying the negative reinforcement (Northouse, 2007).

\section{Organizational learning}

Organizational learning refers to the process of creating, keeping, conveying, and delivering modern or new knowledge in the organization that has a significant influence on behavior/performance. Organizational learning plays an important role in the survival or existence of any type of organization in a highly competitive market because organizational learning significantly influences organizational performance or competitive advantage. According to Sanzo, Santos, García, and Trespalacios (2012), organizational learning refers to a dynamic process of building, acquiring, and integrating knowledge to develop organizational resources and capabilities that will helps to enable the organizations in attaining superior performance. Moreover, this kind of organizational learning is most beneficial for organizations that are growing in an uncertain and dynamic environment to enhance their performance due to the learning environment among employees (Megheirkouni, 2017).

\section{Innovative culture}

Organizational culture is a combination of beliefs, shared values (honesty, diligence, avoid discrimination, loyalty, persistent), norms, behaviors, characteristics, symbols, assumptions, habits, rituals, philosophies, attitude, and practices that organizations used in achieving an advantage over other organizations. According to Wallach (1983), organizational culture consists into three types such as innovative culture, supportive culture, and bureaucratic. In this study, we are focusing on innovative culture in determining organizational performance. Innovative culture refers to a culture where organizations learn from their past beliefs, ideas, and actions that become a reason to failure and focus on the future by using innovative ideas, risk-taking strategies, not only planning but performing, challenging environment, and creative culture that is ignored in 
the past. Moreover, innovative culture is considered as a precious resource for an organization that differentiates your organization with others and has a significant influence on organizational performance. According to Riaz, Ramzan, Ishaq, Akram, and Karim (2012), innovative culture's main focus is on organization inner system and its edge on competitors by encouraging openness to some new ideas.

\section{Hypotheses development}

\section{Leadership styles and organizational performance}

Leadership styles play an important role in determining organizational performance, especially researcher's focus on transformational leadership and transactional leadership to measure their organizational performance. According to Nazarian et al. (2017), leadership styles have gained much attention over a period of time in determining organizational performance. Literature reveals that transformational and transactional leadership is considered as an important indicator in measuring organizational performance (Ekmekcioglu, Aydintan, \& Celebi, 2018; Hafeez, Rizvi, Hasnain, \& Mariam, 2012; Nazarian et al., 2017). Despite this, transformational leadership has significant positive and transactional leadership has a significant negative influence on organizational performance (Al Khajeh, 2018). In addition, some prior studies also elucidated that leadership does not explain organizational performance (Lieberson \& O'Connor, 1972; Podolny, Khurana, \& Hill-Popper, 2005). Therefore, there are mixed finding between leadership styles and organizational performance. The relationship between leadership styles and organizational performance is inconclusive and needs to be further studied. According to RBV theory, organizational learning and innovative culture can explain the relationship between organizational resources (leadership styles) and organizational performance (Barney, 1991). In this study, we are using organizational culture and organizational learning as a mediating variable between leadership styles and organizational performance as prior studies ignore.

$\mathrm{H}_{1}$ : Leadership has a significant influence on organizational performance $\mathrm{H}_{2}$ : Organizational learning significantly mediates between leadership styles and organizational performance

$\mathrm{H}_{3}$ : Innovative culture significantly mediates between leadership styles and organizational performance

\section{Organizational learning, innovative culture, and organizational performance}

Organizational learning plays a significant role in determining SMEs performance. Organizational learning is considered a crucial factor within organizations in explaining their performance (Kim, Watkins, \& Lu, 2017). Various studies demonstrate that researchers pay much attention on organizational learning in determining their performance (Nafei, 2015; Shurafa \& Mohamed, 2016). Organizational culture cannot be ignored in determining organizational performance (Ahmed \& Shafiq, 2014; Gochhayat, Giri, \& Suar, 2017). Moreover, innovative culture has played a significant part in calculating performance (Wei, O'Neill, Lee, \& Zhou, 2013). In the above-mentioned studies, organizational learning and innovative culture are considered vital indicator in measuring organizational performance. 
$\mathrm{H}_{4}$ : Organizational learning has a significant influence on organizational performance

$\mathrm{H}_{5}$ : Innovative culture has a significant influence on organizational performance

\section{Leadership styles, organizational learning, and innovative culture}

Leadership is the most crucial factor for any kind of organizations and it plays a significant role in determining organizational culture. Literature reveal that leadership styles have become an important factor and researchers do not ignore while creating and reinforcing of organizational culture (Chong, Shang, Richards, \& Zhu, 2018; Klein, Wallis, \& Cooke, 2013). Several researchers suggested that leadership styles can influence organization culture (Bass, 1998; Schein, 2010). One of the studies examined the relationship between transformational, transactional, laissez-fair leadership, and organizational culture. Results reveal that transformational and transactional leadership play a significant role in explaining organizational culture (Gholamzadeh, Khazaneh, \& Nabi, 2014). In addition, transactional leadership has a significant influence on innovative work behavior (Faraz, Yanxia, Ahmed, Estifo, \& Raza, 2018). Therefore, this is a debatable area of how organizational culture is derived and whether leadership has any influence to determine organizational culture. Well-known researchers in the field of leadership and culture give their opinion that the behavior of leaders has a direct influence on developing organizational culture and change (Kotter, 1996; Schein, 1992). To become a successful leader, there is a need to evaluate the culture of an organization accurately as well as help followers in understanding it well (Gholamzadeh et al., 2014). The literature demonstrates that leadership is an important indicator in determining organizational culture in recent years but this area still undergoes from the inadequacy of quality data (Fleenor \& Bryant, 2002; Xenikou \& Simosi, 2006).

Literature shows that leadership is a vital factor in determining organizational learning (Liao, Chen, Hu, Chung, \& Liu, 2017; Sun \& Anderson, 2012). Prior studies reveal that transformational leadership has much importance in explaining organizational learning (Liao et al., 2017; Theodore, 2013). Some researchers conclude that transactional leadership plays a significant role in determining organizational learning (Jansen, Vera, \& Crossan, 2009; Vera \& Crossan, 2004). Elshanti (2017) content that leadership styles (transformational leadership) has the most significant indicator in determining organizational learning and recommends that in the future there is a need to study transactional leadership also with organizational learning. Some of the prior studies show that whether the organizations have self-learning abilities, the leadership styles becomes a vital construct that has an influence on organizational learning (Garcia-Morales, Llorens-Montes, \& Verdú-Jover, 2006; Gil, Rodrigo-Moya, \& Morcillo-Bellido, 2018; Jiménez-Jiménez \& Sanz-Valle, 2011). Moreover, transformational leadership is a vital factor in explaining organizational learning (Abazeed, 2018).

$\mathrm{H}_{6}$ : Leadership styles have a significant influence on organizational learning

$\mathrm{H}_{7}$ : Leadership styles have a significant influence on innovative culture

\section{Resource-based view theory}

In this study, RBV theory used as underpinning theory to develop a theoretical framework. RBV theory is considered as an organizational theory which signifies that organizational internal and external resources are significant and management pays 
attention to that resources. According to Barney (1991), organization resources must be rare, imitable, non-substitutable, and valuable to become a source to get a competitive advantage. Human resources and organizational culture are considered as vital resource for organization in explaining organizational performance (Barney, 1991). Literature reveals that there are two major assumption of RBV theory such as resources should be bundled and organizational capabilities underlying production should be heterogeneous across organizations, and these variations might be for long term and imperfectly mobile (Barney, 1991; Wernerfelt, 1989). According to Grant (1991), intangible resources heterogeneity and imperfect transferability prevents the use of the existing market prices in assigning them value. Moreover, organization resources are considered as the inputs that are use into production process, while organizational capabilities deems the capacity that used for both tangible and intangible resources to execute some task (Grant, 1991). In this study, leadership styles, organizational learning, innovative culture, and organizational performance used to develop framework with the help of RBV theory. Leadership styles are considered as vital resource for an organization and influence on organizational performance (Barney, 1991). Organizational learning plays a significant role in enhancing organizational performance in perspective of RBV theory (Makabila, 2018). Innovative culture is considered as a strategic resource for an organization that helps in determining organizational performance (Barney, 1991; Genç, 2013). Figure 1 demonstrates theoretical framework that developed on the base of RBV theory.

\section{Research methodology}

Researchers paid much attention to research methodology portion as this determines the purpose of any kind of research (Rehman, Mohamed, \& Ayoup, 2019). To achieve the research objectives and try to solve the theoretical and practical problem, there is a need to use suitable analysis techniques (Rehman et al., 2019). Therefore, in the current

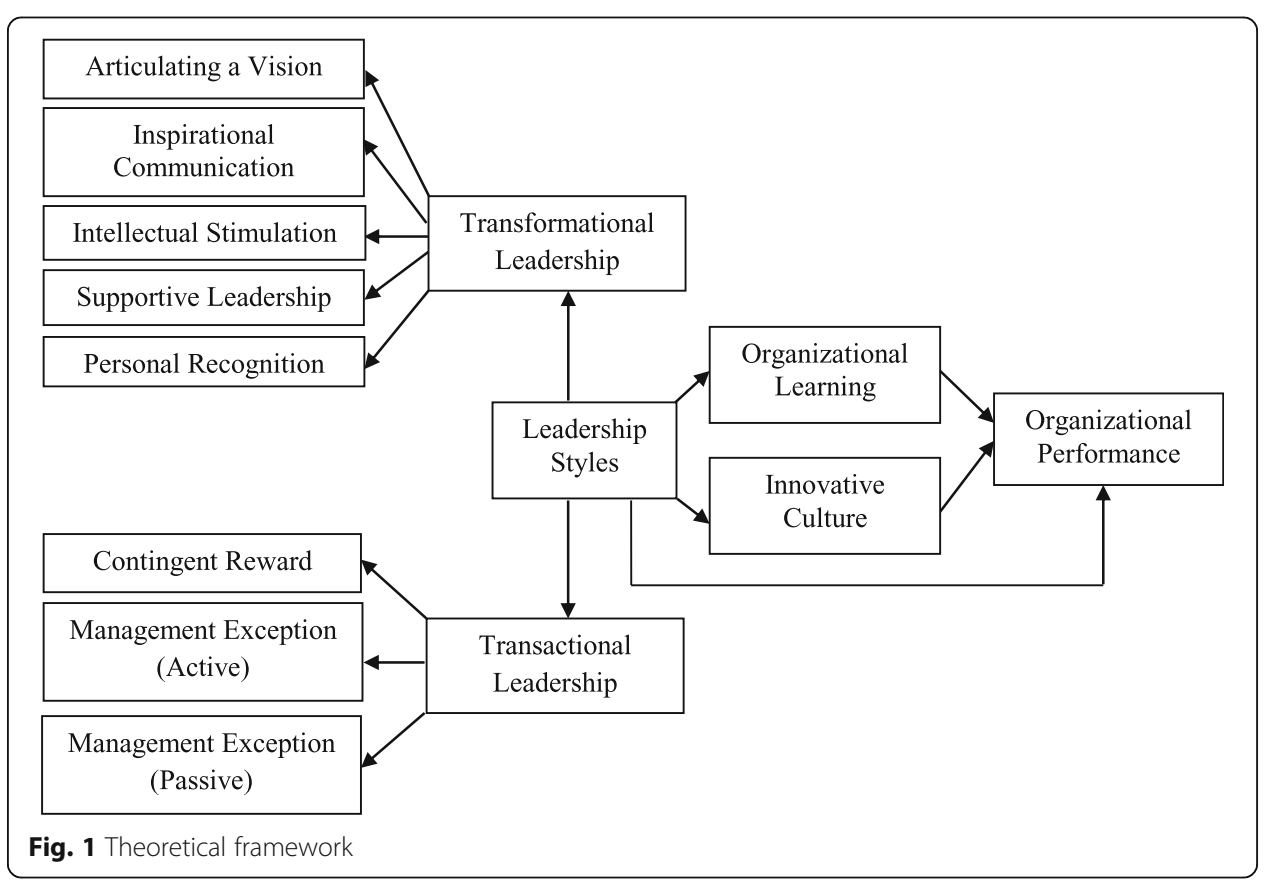


study, to see research nature, research problem, and the research objectives, we are following a quantitative approach and data were collected through a questionnaire at the same time because cross-sectional design used (Rehman et al., 2019). In this study, deductive reasoning approach was used and then linked with the quantitative research design. The reason to use deductive reasoning is that hypotheses were developed on the basis of existing theory and after developing research hypotheses research strategy design to test hypotheses of this study.

\section{Data collection method}

In this study, data were collected to use questionnaires that adapted from some previous studies in the area of leadership styles, organizational learning, innovative culture, and organizational performance. Questionnaires were distributed by postal survey to owners or managers of SMEs in Malaysia.

\section{Questionnaire development}

The theoretical model of this study includes four variables. Every variable of this study measured to use some items. Previous studies used to design questionnaires and items of all variables adapted instead of adopted. The questionnaire consists of two portions. The first portion includes six questionnaires regarding respondent's demographics. The second portion includes 51 items regarding leadership styles, innovative culture, organizational learning, and organizational performance. Considerably, each item of questionnaires in the second portion measured by using five-Likert scale range strongly agrees (5) to strongly disagree (1). Leadership styles consist of transformational leadership and transactional leadership. In the transformational leadership, articulating a vision (three items), supportive leadership (three items), and inspirational communication (three items) were adapted from House (1998), whereas intellectual simulations (three items) and personal recognition (three items) were adapted from Podsakoff, MacKenzie, Moorman and Fetter (1990). In the transactional leadership, contingent rewards (five items), management exception-active (four items), management exception-passive (four items), and management-passive (five items) were adapted from Bass (1995). Organizational learning consists of four items and adapted from Hult (1998). Innovative culture consists of eight items and adapted from Wallach (1983). Finally, organizational performance adapted from two sources, financial performance consists of three items from Henri (2006), and non-financial performance includes eight items adapted from Teeratansirikool, Siengthai, Badir and Charoenngam (2013).

\section{Population and sampling}

This study chooses Malaysian SME's and respondents were owner or managers of SME's. For this study, only listed SME's selected that were on Malaysian public website and a total number of SME's consists 907,065 (SMEinfo, 2018). There were five heads regarding sector in this list such as services, manufacturing, construction, mining and quarrying, and agriculture. A total number of questionnaires distributed among managers/owners were 950 by using postal survey. Five-Likert scale was used in designing questionnaires that range from 1 (strongly disagree) to 5 (strongly agree). There are many reasons to use a five-Likert scale. First, response rate can be improved by using a five-Likert scale because respondents fill the questionnaires with devotion and honesty. 
Second, respondents feel comfortable and easy due to the time constraints factor. Third, the frustration level of respondents minimizes in five-Likert scale as compared to seven-Likert scale. Area cluster sampling is suitable in a situation where population is spread over a wider geographical area (Sekaran \& Bougie, 2016). In this study, we are using area cluster sampling to collect data from managers or owners of SMEs because population is spread over a wider geographical area. Formation of the clusters was based to see states in Malaysia. There are a total of 16 states in Malaysia that are following with SME's portion. Selangor 19.8\%, Kuala Lumpur 14.7\%, Johor 10.8\%, Perak 8.3\%, Pinang 7.4\%, Sarawak 6.7\%, Sabah 6.2\%, Kedah 5.4\%, Kelantan 5.1\%, Pahang 4.1\%, Negeri Sembilan 3.6\%, Malacca 3.5\%, Terengganu 3.2\%, Perlis 0.8\%, Labuan 0.3\%, and Putrajaya $0.1 \%$. Each state is considered as one cluster and from 16 clusters 09 clusters (Selangor, Kuala Lumpur, Johor, Perak, Pinang, Sarawak, Sabah, Kedah, and Kelantan) were randomly chosen because $84.4 \%$ SME's work in these 09 states. According to Sekaran and Bougie (2016), one of the researchers suggested that by using cluster sampling, first, define cluster then choose cluster randomly (Sekaran \& Bougie, 2016). There are various advantages of area cluster sampling that are as follows. First, area cluster sampling minimizes the cost of data collection because it covers cluster that is important and leaves those cluster that is not important. Second, area cluster sampling is useful when concerned respondents spread in a wide area and by using this sampling technique, researchers can cover the major portion of the population (Sekaran \& Bougie, 2016). Third, cluster sampling techniques cover the advantages of two sampling techniques such as stratified random sampling techniques and simple random sampling technique. Fourth, cluster sampling has another advantage that researcher can collect data from one or more clusters. Fifth, area cluster sampling is considered an important sampling technique in the case where respondents spread over a large area.

\section{Sample size}

According to Comrey and Lee (1992), a sample size lesser than 50 is deemed weaker, within 51 to 100 considered weak, within 101 to 200 considered adequate, within 300 is good, 500 respondents considered good, and 1000 is considered excellent. In this study, our respondents were managers or owners as these are persons that have held in SME's and know better about leadership styles, innovative culture, organizational learning, and organizational performance. In addition, managers/owners are educated persons and understand better regarding organization and give better results. A total of 950 questionnaires were distributed by using postal technique. Out of 950 questionnaires, 409 questionnaires returned back, 25 questionnaires were excluded due to misleading and missing values, and 384 questionnaires were used for analysis purpose. Response rate is $43.05 \%$ and after excluding 25 questionnaires, response rate becomes $40.42 \%$. Literature reveals that response rate in postal survey questionnaire was $48.7 \%$ and the current study's response rate is near to that study (Puffer, Porthouse, Birks, Morton, \& Torgerson, 2004).

\section{Data analysis}

In the current paper, we are using SmartPLS 3.2.8 in determining theoretical framework as this tool is a rapidly growing second-generation technique as suggested (Hair, 
Hult, Ringle, \& Sarstedt, 2014). According to Hair, Hult, Ringle, and Sarstedt (2017), bootstrapping is a technique in getting path coefficients and factors loading, and there is a need to run bootstrapping with 5000 subsamples to get significant values. SmartPLS have some of the advantages over other tools like this tool which is superior to perform estimation as in the comparison of regression, no issue of normality and multicollinearity test, and best for any kind of theoretical framework either simple or complex. In addition, the literature demonstrates that partial least squares structural equation modeling (PLS-SEM) is superior in calculating outcomes and establishing variable validities as compared to covariance-based structural equation modeling (CB-SEM) (Afthanorhan, 2013; Hair et al., 2014). There is a need to calculate two research models in PLS-SEM such as measurement model (outer model) and structural model (inner model).

\section{Measurement model}

In this paper, we calculate the measurement (outer) model with the help of two things such as convergent validity and discriminant validity.

\section{Convergent validity}

Convergent validity means the level to see items of a constructed measure the same construct. According to Zhou (2013), convergent validity means a situation where items of a variable reflect effectively to their associated indicator. Hair, Hult, Ringle, and Sarstedt (2013) stated that calculate three things to see convergent validity of a construct like average variance-extracted (AVE), factor loadings, and the final one is composite reliability. The standardized values of these indicators are as follow; AVE and factor loadings at least 0.50 and CR value must be higher than 0.70 (Hair et al., 2013). To get better results regarding CR and AVE researchers should delete all those items that have factors loadings less than 0.50 as recommended (Hayduk \& Littvay, 2012). In addition, delete items that have factor loadings less than 0.50 makes a sound theoretical model. In this study, few of the items deleted due to less factor loadings such as IC2, IS3, SL1, PR1, CR1, CR2, CR5, MEA1, MEA4, INCUL4, INCUL5, INCUL6, INCUL7, INCUL8, OP2, OP4, OP6, OP9, OP10, and OP11. Table 2 demonstrates that factors loadings, CR, and AVE values above than the criterion value. According to George and Mallery (2003), a variable that has Cronbach's alpha at least 0.70 considers excellent. Table 3 demonstrates that all variables meet this criterion. Hence, this study validates all the conditions that require in calculating the convergent validity of the theoretical model (Bagozzi \& Yi, 1988). Figure 2 demonstrates that we have conceptualized leadership styles as a third-order variable with organizational learning, innovative culture, and organizational performance. In this study, we use repeated indicator approach for leadership styles. Repeated indicators approach has the ability to estimate all variables at the same time rather than higher order and lower order dimensions one by one (Becker, Klein, \& Wetzels, 2012).

\section{Discriminant validity}

Discriminant validity refers to a situation that tells that every variable of theoretical model differs from another variable (Rehman et al., 2019). In this study, discriminant 


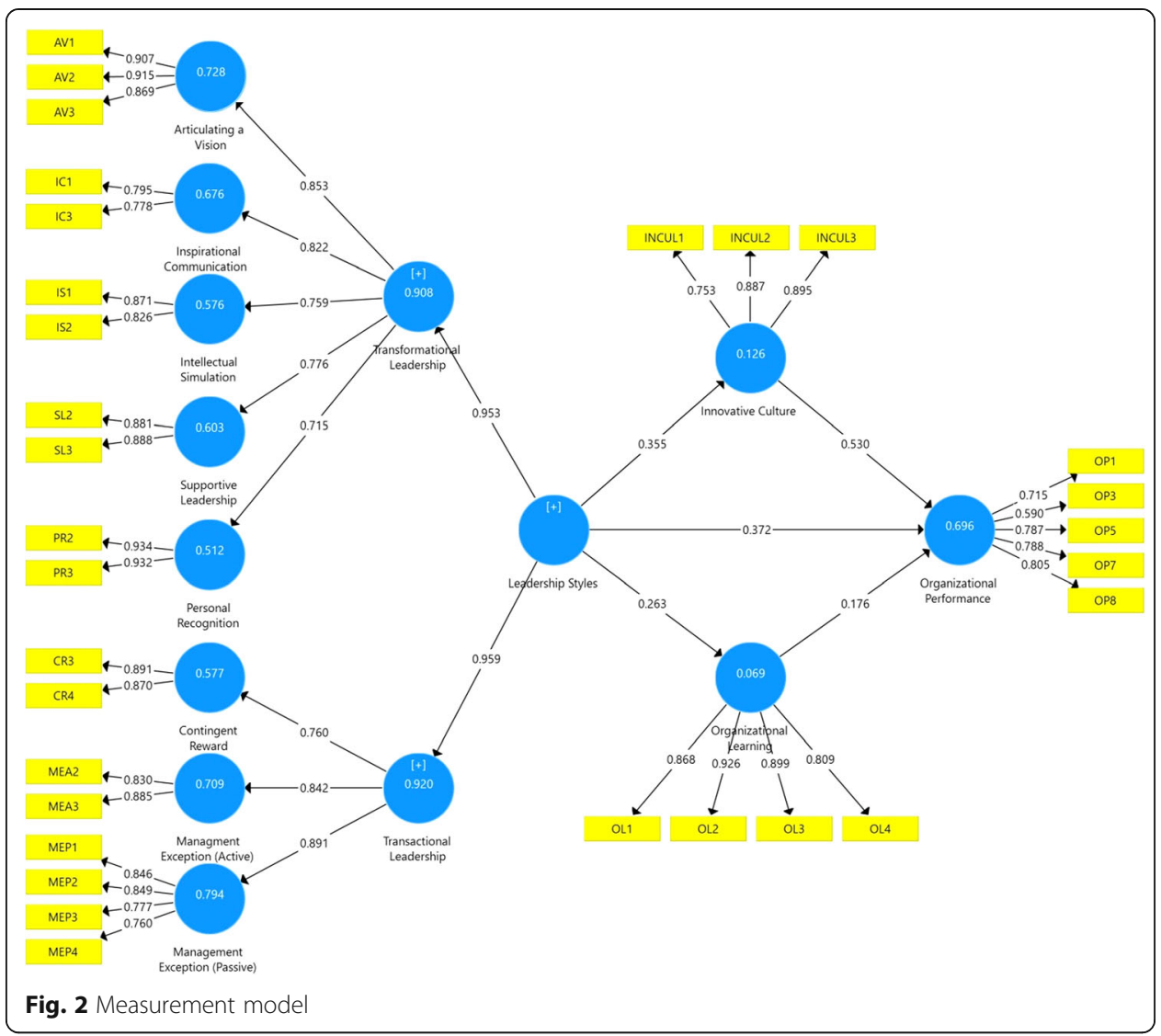

validity calculated by using Fornell and Larcker (1981) recommended the method. Discriminant validity can be calculated by using one of the methods. First, compare AVE with squared correlations. Second, compare AVE square root values with the correlation values. Rehman et al. (2019) stated that AVE square root values in upper diagonals should be greater than other values in the table in terms of rows as well as columns Table 4 demonstrates that this study fulfills the above-mentioned criterion.

\section{Structural model and hypotheses testing}

In this section, we examined the hypotheses of this study by using SmartPLS 3.2.8 techniques like algorithm and bootstrapping. According to Hair et al. (2017), bootstrapping is a technique in getting path coefficients and factors loading, and there is a need to run bootstrapping with 5000 subsamples to get significant values. In this paper, we followed 5000 subsamples criterion. Table 5 stated that the current study has a total of seven hypotheses, out of which five direct hypotheses and two indirect/mediating hypotheses. Figure 3 shows the results of structural model.

\section{Results}

Table 5 shows that leadership styles have significant influence on organizational performance with beta value $=0.372, t$ value $=12.543, p$ value $=0.000$, and supported $\mathrm{H}_{1}$. In addition, organizational learning significantly mediates between leadership styles and organizational performance with beta value $0.046, t$ value $=3.735$, and $p$ value $=0.000$ 
Table 2 Factor loadings, average variance extracted (AVE), and composite reliability (CR)

\begin{tabular}{|c|c|c|c|c|c|c|}
\hline First-order constructs & $\begin{array}{l}\text { Second-order } \\
\text { constructs }\end{array}$ & $\begin{array}{l}\text { Third-order } \\
\text { construct }\end{array}$ & Items & $\begin{array}{l}\text { Factor } \\
\text { loading }\end{array}$ & AVE & $C R$ \\
\hline \multirow[t]{3}{*}{ Articulating a vision } & & & $A V 1$ & 0.907 & 0.805 & 0.925 \\
\hline & & & AV2 & 0.915 & & \\
\hline & & & AV3 & 0.869 & & \\
\hline \multirow{2}{*}{$\begin{array}{l}\text { Inspirational } \\
\text { communication }\end{array}$} & & & $\mathrm{IC} 1$ & 0.795 & 0.618 & 0.764 \\
\hline & & & IC3 & 0.778 & & \\
\hline \multirow[t]{2}{*}{ Intellectual simulation } & & & IS1 & 0.871 & 0.720 & 0.837 \\
\hline & & & IS2 & 0.826 & & \\
\hline \multirow[t]{2}{*}{ Supportive Leadership } & & & SL2 & 0.881 & 0.783 & 0.878 \\
\hline & & & SL3 & 0.888 & & \\
\hline \multirow[t]{7}{*}{ Personal recognition } & & & PR2 & 0.934 & 0.871 & 0.931 \\
\hline & & & PR3 & 0.932 & & \\
\hline & Transformational & & Articulating a vision & 0.853 & 0.618 & 0.889 \\
\hline & & & $\begin{array}{l}\text { Inspirational } \\
\text { communication }\end{array}$ & 0.822 & & \\
\hline & & & Intellectual simulation & 0.759 & & \\
\hline & & & Supportive leadership & 0.776 & & \\
\hline & & & Personal recognition & 0.715 & & \\
\hline \multirow[t]{2}{*}{ Contingent Reward } & & & CR3 & 0.891 & 0.775 & 0.873 \\
\hline & & & CR4 & 0.870 & & \\
\hline \multirow{2}{*}{$\begin{array}{l}\text { Management } \\
\text { exception (active) }\end{array}$} & & & MEA2 & 0.830 & 0.736 & 0.848 \\
\hline & & & MEA3 & 0.885 & & \\
\hline \multirow{9}{*}{$\begin{array}{l}\text { Management } \\
\text { exception (active) }\end{array}$} & & & MEP1 & 0.846 & 0.642 & 0.877 \\
\hline & & & MEP2 & 0.849 & & \\
\hline & & & MEP3 & 0.777 & & \\
\hline & & & MEP4 & 0.760 & & \\
\hline & Transactional & & Contingent Reward & 0.760 & 0.693 & 0.871 \\
\hline & & $\begin{array}{l}\text { Leadership } \\
\text { styles }\end{array}$ & $\begin{array}{l}\text { Management } \\
\text { Exception (active) }\end{array}$ & 0.842 & 0.913 & 0.955 \\
\hline & & & $\begin{array}{l}\text { Management } \\
\text { Exception (passive) }\end{array}$ & 0.891 & & \\
\hline & & & $\begin{array}{l}\text { Transformational } \\
\text { Leadership }\end{array}$ & 0.953 & & \\
\hline & & & $\begin{array}{l}\text { Transactional } \\
\text { leadership }\end{array}$ & 0.959 & & \\
\hline \multirow[t]{3}{*}{ Innovative culture } & & & INCUL1 & 0.753 & 0.718 & 0.884 \\
\hline & & & INCUL2 & 0.887 & & \\
\hline & & & INCUL3 & 0.895 & & \\
\hline \multirow{4}{*}{$\begin{array}{l}\text { Organizational } \\
\text { learning }\end{array}$} & & & OL1 & 0.868 & 0.769 & 0.930 \\
\hline & & & OL2 & 0.926 & & \\
\hline & & & OL3 & 0.899 & & \\
\hline & & & OL4 & 0.809 & & \\
\hline \multirow{4}{*}{$\begin{array}{l}\text { Organizational } \\
\text { performance }\end{array}$} & & & OP1 & 0.715 & 0.550 & 0.858 \\
\hline & & & OP3 & 0.590 & & \\
\hline & & & OP5 & 0.787 & & \\
\hline & & & OP7 & 0.788 & & \\
\hline
\end{tabular}


Table 2 Factor loadings, average variance extracted (AVE), and composite reliability (CR) (Continued)

\begin{tabular}{|c|c|c|c|c|c|}
\hline First-order constructs & $\begin{array}{l}\text { Second-order } \\
\text { constructs }\end{array}$ & $\begin{array}{l}\text { Third-order } \\
\text { construct }\end{array}$ & Items & $\begin{array}{l}\text { Factor } \\
\text { loading }\end{array}$ & AVE $\quad C R$ \\
\hline & & & OP8 & 0.805 & \\
\hline
\end{tabular}

and supported our hypotheses $\mathrm{H}_{2}$. Moreover, innovative culture significantly mediates between leadership styles and organizational performance with beta value $=0.189, t$ value $=6.338, p$ value $=0.000$, and accepted our hypotheses $\mathrm{H}_{3}$. Meanwhile, organizational learning has significant influence on organizational performance with beta value $=0.176, t$ value $=5.159, p$ value $=0.000$, and accepted $\mathrm{H}_{4}$. In addition, innovative culture has significant influence on organizational performance with beta value $=0.530, t$ value $=16.918, p$ value $=0.000$, and supported $H_{5}$. Moreover, leadership styles have significant influence on organizational learning with beta value $=0.263$, $t$ value $=5.282, p$ value $=0.000$, and accepted $\mathrm{H}_{6}$. Finally, leadership styles have a significant influence on innovative culture with beta value $=0.355, t$ value $=6.697, p$ value $=0.000$, and supported our hypotheses $\mathrm{H}_{7}$.

\section{Effect size}

$R^{2}$ refers to the strength of the theoretical model that how well endogenous variable explained due to all exogenous variables. Hair et al. (2014) suggested that from theoretical framework, eliminate one exogenous construct and run again theoretical model, later again add that eliminating construct and eliminate another exogenous construct; this process continues until very last exogenous construct excludes. Therefore, a difference in the $R^{2}$ value due to the eliminating variable from the theoretical model should be used to find the contribution of that eliminating variable on endogenous construct (Hair et al., 2014). $\mathrm{F}^{2}$ has three types such as small effect size (0.02), medium effect size (0.15), and the last one is large effect size (0.35) as suggested (Cohen, 1988). Leadership styles and innovative culture have a large effect size 0.325 and 0.671 respectively. Organizational learning has a small effect size such as 0.082 .

\section{The predictive relevance of study model}

Predictive relevance of the theoretical model is estimated by using two things like $R^{2}$ and cross-validated redundancy (Geisser, 1974; Stone, 1974). $R^{2}$ computed by running the algorithm and it shows the degree of variance of the endogenous variable that explained due to all exogenous variables. Table 6 demonstrates that $12.6 \%$ innovative culture and $6.9 \%$ organizational learning were explained by leadership styles. Moreover, organizational performance explained $69.6 \%$ due leadership styles, innovative culture,

Table 3 Cronbach's alpha

\begin{tabular}{ll}
\hline Variable & Cronbach's alpha \\
\hline Leadership styles & 0.926 \\
Innovative culture & 0.800 \\
Organizational learning & 0.899 \\
Organizational performance & 0.792 \\
\hline
\end{tabular}




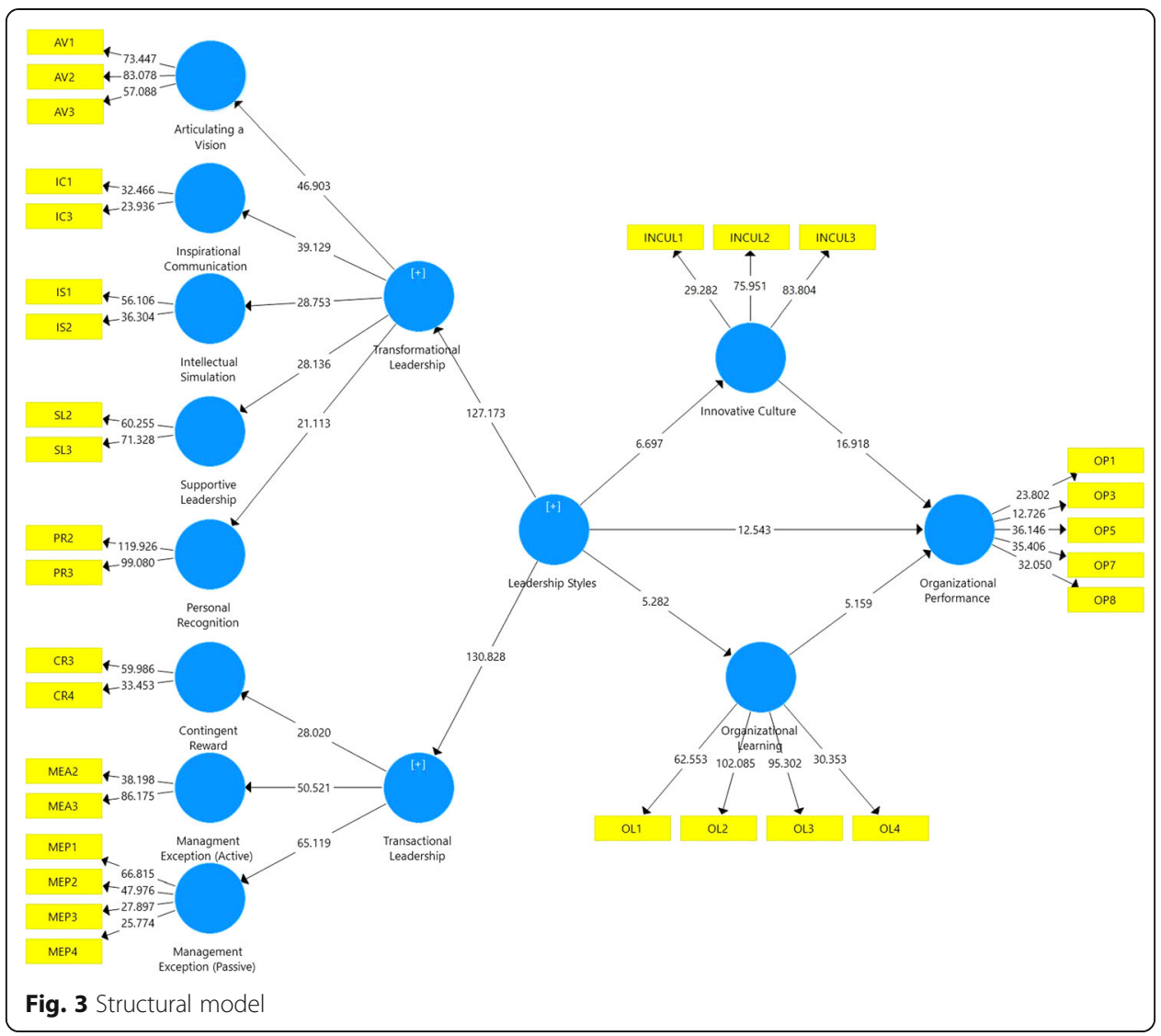

and organizational learning. Cohen (1988) recommends that $R^{2}$ within the range of 0.02 to 0.13 is considered weak, $R^{2}$ within 0.13 to 0.26 is considered moderate, and higher than 0.26 is considered substantial. In the current paper, organizational performance was deemed substantial and organizational learning and innovative culture were considered weak. The second requirement is $Q^{2}$ that determines the quality of the theoretical model by using the blindfolding technique in SmartPLS. Prior researchers recommended that $Q^{2}$ value must be greater than zero (Chin, 1998; Fornell, 1994; Henseler, Ringle, \& Sinkovics, 2009). However, this paper fulfills the above-mentioned requirement regarding $Q^{2}$, as $Q^{2}$ of innovative culture 0.083 , organizational learning 0.049 , and organizational performance 0.356 as mentioned in Table 6 .

\section{Model fit}

Researchers should be very cautious to report and use model fit in PLS-SEM (Hair et al., 2017). The standardized root mean square residual (SRMR) is based on the transforming of both predicted and covariance matrix into correlation matrices. SRMR value should be less than 0.08 or 0.10 as suggested by $\mathrm{Hu}$ and Bentler (1998). The values of both d_G and d_ULS in itself do not pertain any value and only bootstrap findings of the correct model fit measures allow an explanation of the results (Hair, Hult, Ringle, \& Sarstedt, 2016). Normed fit index (NFI) computes the $\mathrm{Chi}^{2}$ value of the proposed model and compares this value with benchmark (Hair et al., 2016). Table 7 demonstrates the model fit values. 
Table 4 Discriminant validity

\begin{tabular}{lllll}
\hline Variables & LS & INCUL & OL & OP \\
\hline LS & 0.955 & & & \\
INCUL & 0.353 & 0.847 & & \\
OL & 0.257 & 0.372 & 0.877 & 0.747 \\
OP & 0.622 & 0.699 & 0.455 & \\
\hline
\end{tabular}

Diagonals represent the square root of AVE, while the off-diagonals represent the correlations

\section{Discussion}

The purpose of this paper is to determine the mediating effect of innovative culture and organizational learning between leadership styles and organizational performance in SMEs of Malaysia. The results of this paper elucidate that leadership style has a significant positive influence on organizational performance. This significant result tells that SMEs in Malaysia give importance to transformational leadership (articulating a vision, inspirational communication, intellectual simulation, supportive leadership, and personal recognition) and transactional leadership (contingent rewards, management exception active, and management exception passive) in their decision making to enhance their performance. The findings are similar with the work of Nazarian et al. (2017) that both leadership styles transactional and transformational leadership are considered important in determining and increase organizational performance. Nazarian et al. (2017) collected data from 177 young professional in Germany. Moreover, innovative culture has a significant influence on organizational performance and tells the story that Malaysian SMEs have an innovative culture that helps to increase organizational performance. The results are consistent with Wei et al. (2013) in which the author collected data from 3960 individual employees in Chinese organizations. In addition, organizational learning has a significant influence on organizational performance and gives the idea that Malaysian SMEs have a learning culture in the organizations that boost up their performance. The work is similar to the previous work (Nafei, 2015; Shurafa \& Mohamed, 2016) that reveals that organization learning plays an important role in enhancing organizational performance. Moreover, leadership styles have a significant and positive influence on innovative culture that tells the story that leader in Malaysian SMEs has an influence in developing an organizational culture in terms of innovativeness. The findings are similar to the findings of Faraz et al. (2018) that leadership determines innovative culture and authors collect data from 260 middle level managers from Power sector in Pakistan. Furthermore, leadership styles have a

Table 5 Direct relationships

\begin{tabular}{llllllll}
\hline Hypotheses & Paths & Original sample & Sample mean & Std. Dev. & $T$ values & $P$ values & Results \\
\hline $\mathrm{H}_{1}$ & $\mathrm{LS} \rightarrow \mathrm{OP}$ & 0.372 & 0.372 & 0.030 & 12.543 & 0.000 & Accepted \\
$\mathrm{H}_{2}$ & $\mathrm{LS} \rightarrow \mathrm{OL} \rightarrow \mathrm{OP}$ & 0.046 & 0.047 & 0.012 & 3.735 & 0.000 & Accepted \\
$\mathrm{H}_{3}$ & $\mathrm{LS} \rightarrow \mathrm{INCUL} \rightarrow \mathrm{OP}$ & 0.189 & 0.187 & 0.030 & 6.338 & 0.000 & Accepted \\
$\mathrm{H}_{4}$ & $\mathrm{OL} \rightarrow \mathrm{OP}$ & 0.176 & 0.179 & 0.034 & 5.159 & 0.000 & Accepted \\
$\mathrm{H}_{5}$ & $\mathrm{INCUL} \rightarrow \mathrm{OP}$ & 0.530 & 0.529 & 0.031 & 16.918 & 0.000 & Accepted \\
$\mathrm{H}_{6}$ & $\mathrm{LS} \rightarrow \mathrm{OL}$ & 0.263 & 0.264 & 0.050 & 5.282 & 0.000 & Accepted \\
$\mathrm{H}_{7}$ & $\mathrm{LS} \rightarrow$ INCUL & 0.355 & 0.355 & 0.053 & 6.697 & 0.000 & Accepted \\
\hline \multicolumn{2}{l}{ L Leadership styles, INCUL Innovative culture, OL Organizational learning, OP Organizational performance } &
\end{tabular}


Table 6 The predictive relevance of study model

\begin{tabular}{lll}
\hline Total & $R^{2}$ & $Q^{2}$ \\
\hline Innovative culture & 0.126 & 0.083 \\
Organizational learning & 0.069 & 0.049 \\
Organizational performance & 0.696 & 0.356 \\
\hline
\end{tabular}

significant influence on organizational learning that shows that Malaysian SMEs works on organizational learning through their leaders. The findings are consistent with the findings of Garcia-Morales et al. (2006) and Jiménez-Jiménez and Sanz-Valle (2011)). Finally, innovative culture and organizational learning plays a significant mediating role between leadership styles and organizational performance. It gives benefits to Malaysian SMEs that in determining organizational performance do not ignore innovative culture and organizational learning. The current study differs from others studies in terms of leadership styles covers (articulating a vision, inspirational communication, intellectual stimulation, supportive leadership, personal recognition, contingent rewards, management exception (active), and management exception (passive)). Furthermore, this study differs in terms of culture because less attention has been paid on innovative culture as a mediating variable.

\section{Theoretical implication}

The current study contributes theoretically in terms of determining the influence on the mediating effect of two constructs like organizational learning and innovative culture between leadership styles and organizational performance that prior studies largely ignored. By incorporating leadership styles, innovative culture, organizational learning, and organizational performance in a single model, the current study is in a position to answer further studies to be held. Furthermore, organizational learning and innovative culture that can be further used to explain the relationship between leadership styles and organizational performance in SMEs performance. This is the first study that uses leadership styles at third-order in examining organizational performance through innovative culture and organizational learning to use RBV theory.

\section{Practical implication}

The results of the current paper have various practical contributions that give benefits to owners/managers of SMEs in improving organizational performance. The study elucidates that leadership styles (transformational and transactional) play an important role in determining organizational learning and innovative culture, which ultimately has a significant influence on organizational performance. The current study suggests that owners/managers should consider innovative culture and organizational learning if

Table 7 Model fit

\begin{tabular}{lll}
\hline Total & Structured model & Measured model \\
\hline SRMR & 0.073 & 0.079 \\
d_ULS & 49.962 & 54.350 \\
d_G & n/a & n/a \\
Chi-square & Infinite & Infinite \\
NFI & n/a & n/a \\
\hline
\end{tabular}


they want to enhance organizational performance. Moreover, innovative culture gives fruitful results in that situation where organizations have also learning the culture. Employees have the ability to learn something new that will help in enhancing their performance which ultimately boosts up organizational performance. Today, organizations work on innovative culture in determining organizational performance. For instance, ten examples of organizations that have a fantastic cultures like Zappos, Warby Parker, South Airlines, Twitter, Chevron, Square Space, Google, REI, Facebook, and Adobe. In addition, this study suggests that in organizations that have enthusiastic leaders but do not have learning environment as their employees only do their job just for duty and not interested to learn new knowledge, those organizations performance increase but not up to that mark. On the other hand, those organizations that have good leaders and also have an innovative culture and learning environment are successful in the market. Malaysia is a country that is rapidly climbing up in global innovation index and now ranked at 37th all over the world and there are some leaders that share their corporate innovation advice such as Nathanael Noiraud, Galia Forouzesh, Sean Wong, Leon Jackson, Hazim Nazlan, Melissa Woo, Suresh Naidu Sadasivan, Arnold Aranez, and Namanzee Harris (Campus, C, 2018, March 27). Hence, this study contributes practically that managers/owners do not ignore leadership styles, organizational learning, and innovative culture in measuring organizational performance.

\section{Limitations and suggestions}

This study focuses on SMEs that are working in Malaysia. Although the results of this paper significantly give contribution to the literature regarding leadership styles, innovative culture, organizational learning, and organizational performance, the findings of this paper cannot be generalized in the entire world. Therefore, there is a need to further study the current theoretical model in other countries to generalize the findings. Furthermore, in this study, we use only leadership styles, organizational learning, and innovative culture to determine organizational performance. In the future, there is a need to add some other constructs such as market orientation, entrepreneurial orientation, organizational capabilities, knowledge management, and business strategy to measures organizational performance in both developing and developed economies. In addition, corporate governance, management control, and market orientation can be used as a mediating variable between leadership styles and organizational performance.

\section{Conclusion}

This study concludes that leadership styles have a significant influence on organizational learning, innovative culture, and organizational performance. Innovative culture and organizational learning have a significant influence on organizational performance. It means that researchers cannot ignore leadership styles to determine organizational performance. Leadership styles also enhance positively organizational learning and innovative culture that contribute positively to organizational performance. Leadership styles both transformational leadership and transactional leadership used in this study that provides fruitful results for SMEs in Malaysia. Moreover, innovative culture and organizational learning significantly mediate between leadership styles and organizational performance. Therefore, the findings of the current papers show that the resource-based view (RBV) theory fully applied on the study model. 


\section{Appendix}

Table 8 Scale Items

Leadership styles

Transformational Leadership

Articulating a vision

1. Has a clear understanding of where we are going

2. Has a clear sense of where he/she wants our unit to be in 5 years

3. Has no idea where the organization is going (R)a

Inspirational communication

1. Says things that make employees proud to be a part of this organization

2. Says positive things about the work unit

3. Encourages people to see changing environments as situations full of opportunities Intellectual stimulation

1. Challenges me to think about old problems in new ways

2. Has ideas that have forced me to rethink some things that I have never questioned before

3. Has challenged me to rethink some of my basic assumptions about my work Supportive leadership

1. Considers my personal feelings before acting

2. Behaves in a manner which is thoughtful of my personal needs

3. Sees that the interests of employees are given due consideration

Personal recognition

1. Commends me when I do a better than average job

2. Acknowledges improvement in my quality of work

3. Personally compliments me when I do outstanding work

Transactional leadership

Contingent reward

1. Provides me with assistance in exchange for my efforts

2. Discusses in specific terms that is responsible for achieving performance target

3. Makes clear what one can expect to receive when performance goals are achieved

4. Expresses satisfaction when I meet expectations

5. Makes innovative suggestions to improve department

Management exception (active)

1. Focuses attention on irregularities, mistakes, exceptions and deviations from standards

2. Concentrates his/her full attention on dealing with mistakes, complains and failures

3. Keep track of all mistakes

4. Direct my attentions to failures to meet standards

Management exception (passive)

1. Fails to interfere until problems become serious

2. Waits for things to go wrong before taking action

3. Shows that he/she is a firm believer in 'if it is not broke down do not fix it'

4. Demonstrates that problems must become chronic before I take action

Organizational performance

Financial performance

1. My organization profit increase gradually within the last 3 years

2. My organization sales volume increase gradually within the last 3 years

3. My organization return on investment increase gradually within the last 3 years 
Table 8 Scale Items (Continued)

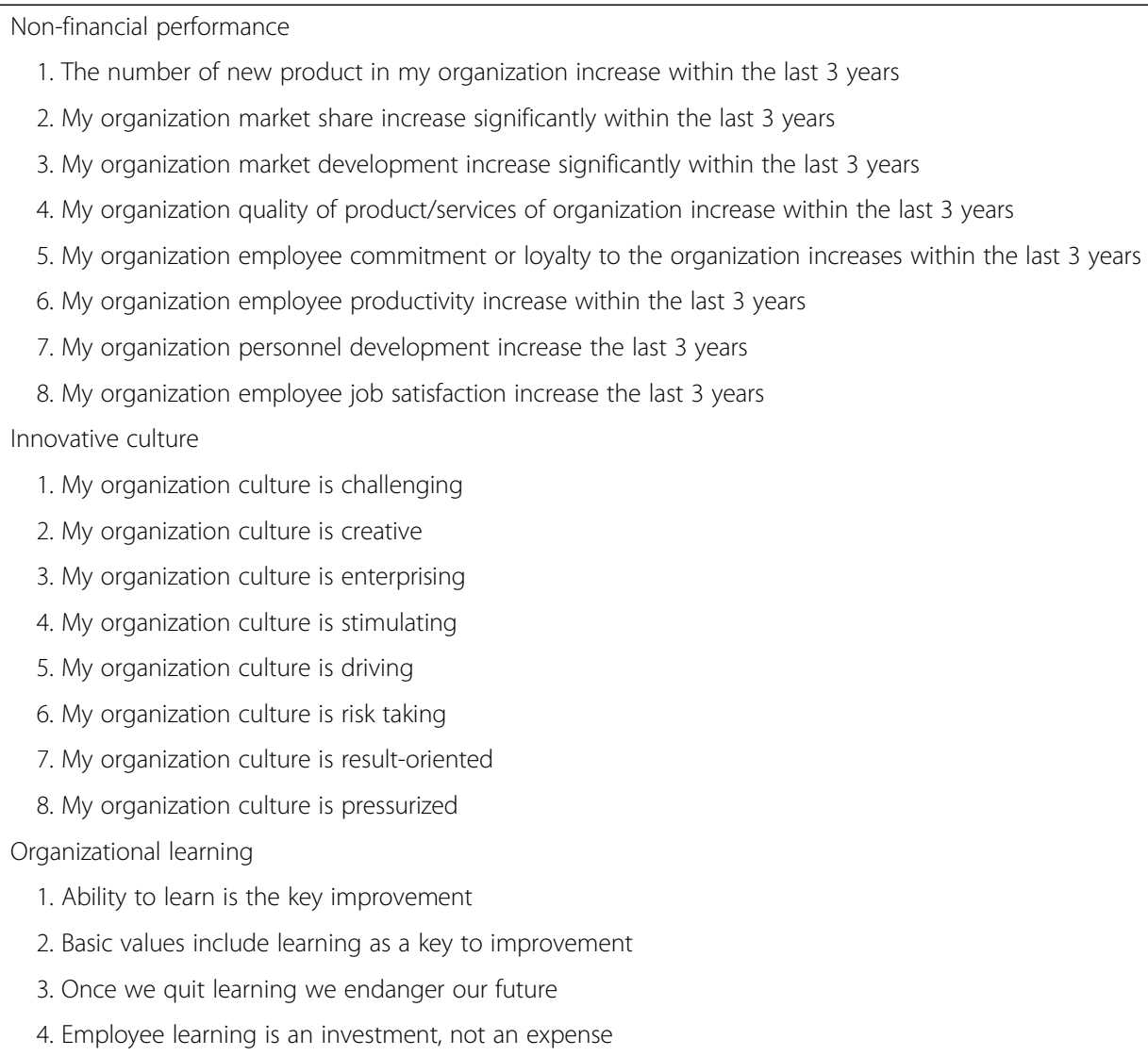

\section{Abbreviations}

AVE: Average variance extracted; CR: Composite reliability; IC: Innovative culture; LS: Leadership styles;

OL: Organizational learning; OP: Organizational performance; RBV: Resource-based view theory

\section{Acknowledgements}

We would thankful to "Associate Professor Dr Rapiah Mohamed" that gives us the valuable instructions and make us capable to produce good research.

\section{Funding}

The authors received no funding for the design of the study, data collection, analysis, and interpretation of data or the writing of the manuscript.

\section{Availability of data and materials}

The dataset used and analyzed during this study is available from the corresponding author on reasonable request.

\section{Authors' contributions}

The corresponding author "SUR" presented the main idea and worked on key section of this study, methodology, and analysis. The author, namely AB, majorly worked on literature of this study, discussion, and conclusion. The author, namely $\mathrm{NIC}$, worked on corrections. All the authors proof read the whole paper. All authors read and approved the final manuscript.

\section{Competing interests}

The authors declare that they have no competing interests.

\section{Publisher's Note}

Springer Nature remains neutral with regard to jurisdictional claims in published maps and institutional affiliations. 


\section{Author details}

${ }^{1}$ Tunku Puteri Intan Safinaz School of Accountancy, Universiti Utara Malaysia, Changlun, Malaysia. ${ }^{2}$ Department of Business Management, Universiti Utara Malaysia, Changlun, Malaysia. ${ }^{3}$ Department of Business Administration, University of the Punjab, Gujranwala Campus, Gujranwala, Pakistan.

Received: 17 January 2019 Accepted: 27 March 2019

Published online: 30 April 2019

\section{References}

Abazeed, R. A. M. (2018). Impact of transformational leadership style on organizational learning in the Ministry of Communication and Information Technology in Jordan.

Abdul-Halim, H., Ahmad, N. H., Geare, A., \& Thurasamy, R. (2018). Innovation culture in SMEs: The importance of organizational culture, organizational learning and market orientation. Entrepreneurship Research Journal. https://doi.org/10.1515/erj-2017-0014.

Afthanorhan, W. (2013). A comparison of partial least square structural equation modeling (PLS-SEM) and covariance based structural equation modeling (CB-SEM) for confirmatory factor analysis. International Journal of Engineering Science and Innovative Technology, 2(5), 198-205.

Ahmed, M., \& Shafiq, S. (2014). The impact of organizational culture on organizational performance: A case study on telecom sector. Global Journal of Management and Business Research, 14(3).

Al Khajeh, E. H. (2018). Impact of leadership styles on organizational performance.

Al-Malki, M., \& Juan, W. (2018). Leadership styles and job performance: A literature review. Journal of International Business Research and Marketing, 3(3), 40-49.

Avolio, B. J., Bass, B. M., \& Zhu, F. W. W. (2004). Multifactor leadership questionnaire: manual and sampler set: Mind garden, Incorporated.

Aziz, R., Abdullah, M., Tajudin, A., \& Mahmood, R. (2013). The effect of leadership styles on the business performance of SMEs in Malaysia.

Bagozzi, R. P., \& Yi, Y. (1988). On the evaluation of structural equation models. Journal of the Academy of Marketing Science, 16(1), 74-94.

Barbuto, J. E. (1997). Taking the charisma out of transformational leadership. Journal of Social Behavior and Personality, 12(3), 689-697.

Barney, J. B. (1991). Firm resources and sustained competitive advantage. Journal of Management, 17(1), 99-120.

Bass, B. M. (1985). Leadership and performance beyond expectations. Beltsville Collier Macmillan.

Bass, B. M. (1990). From transactional to transformational leadership: Learning to share the vision. In Leadership: Understanding the dynamics of power and influence in organizations (pp. 318-333).

Bass, B. M. (1995). Theory of transformational leadership redux. The Leadership Quarterly, 6(4), 463-478.

Bass, B. M. (1998). Transformational leadership: Industry, military, and education impact. Newjersey: Lawrence Erlbaum Associates.

Bass, B. M., \& Avolio, B. J. (1990). The implications of transactional and transformational leadership for individual, team, and organizational development. Research in Organizational Change and Development, 4(1), 231-272.

Bass, B. M., \& Riggio, R. E. (2006). Transformational leadership: Psychology press.

Becker, J.-M., Klein, K., \& Wetzels, M. (2012). Hierarchical latent variable models in PLS-SEM: Guidelines for using reflectiveformative type models. Long Range Planning, 45(5-6), 359-394.

Bryman, A. (2007). Effective leadership in higher education: A literature review. Studies in Higher Education, 32(6), 693-710.

Brymer, E., \& Gray, T. (2006). Effective leadership: Transformational or transactional? Journal of Outdoor and Environmental Education, 10(2), 13

Campus, C. (2018). 9 Leaders in Malaysia share their corporate innovation advice. from https://www.collectivecampus.com.au/ blog/9-leaders-in-malaysia-share-their-corporate-innovation-advice

Chin, W. W. (1998). Commentary: Issues and opinion on structural equation modeling.Management Information Systems Research Center, 22, 1-11.

Chong, M. P., Shang, Y., Richards, M., \& Zhu, X. (2018). Two sides of the same coin? Leadership and organizational culture. Leadership \& Organization Development Journal, 39(8), 975-994.

Cohen, J. (1988). Statistical power analysis for the behavioral sciences. 2nd. Hillsdale: Erlbaum.

Comrey, A. L., \& Lee, H. B. (2013). A first course in factor analysis (2nd ed.). New York: Psychology Press.

Daft, R. L. (2014). The leadership experience. Boston: Cengage.

Ekmekcioglu, E. B., Aydintan, B., \& Celebi, M. (2018). The effect of charismatic leadership on coordinated teamwork: A study in Turkey. Leadership \& Organization Development Journal, 39(8), 1051-1070.

Elshanti, M. (2017). Transformational leadership style and organizational learning: The mediate effect of organizational culture. International Business and Management, 15(2), 1-14.

Faraz, N. A., Yanxia, C., Ahmed, F., Estifo, Z. G., \& Raza, A. (2018). The influence of transactional leadership on innovative work behavior-a mediation model. European Journal of Business and Social Sciences, 7(01), 51-62.

Fleenor, J. W., Bryant, C. (2002). Leadership effectiveness and organizational culture: An exploratory study. Paper presented at the Meeting of the Society for Industrial and Organizational Psychology.

Fornell, C. (1994). Partial least squares. Advanced Methods of Marketing Research, 407, 52-78.

Fornell, C., \& Larcker, D. F. (1981). Evaluating structural equation models with unobservable variables and measurement error. Journal of Marketing Research, 18(1), 39-50.

Franco, M., \& Matos, P. G. (2015). Leadership styles in SMEs: A mixed-method approach. International Entrepreneurship and Management Journal, 11(2), 425-451.

Garcia-Morales, V. J., Llorens-Montes, F. J., \& Verdú-Jover, A. J. (2006). Antecedents and consequences of organizational innovation and organizational learning in entrepreneurship. Industrial Management and Data Systems, 106(1), 21-42.

Geisser, S. (1974). A predictive approach to the random effect model. Biometrika, 61(1), 101-107.

Genç, K. Y. (2013). Culture as a strategic resource for organizations and an assessment on cultures of Turkish large firms. Procedia-Social and Behavioral Sciences, 75, 525-531. 
George, D., \& Mallery, M. (2003). Using SPSS for windows step by step: A simple guide and reference.

Gholamzadeh, D., Khazaneh, A., \& Nabi, M. (2014). The impact of leadership styles on organizational culture in Mapsa company. Management Science Letters, 4(9), 2161-2170.

Gil, A. J., Rodrigo-Moya, B., \& Morcillo-Bellido, J. (2018). The effect of leadership in the development of innovation capacity: A learning organization perspective. Leadership \& Organization Development Journal, 39(6), 694-711.

Gochhayat, J., Giri, V. N., \& Suar, D. (2017). Influence of organizational culture on organizational effectiveness: The mediating role of organizational communication. Global Business Review, 18(3), 691-702.

Gorondutse, A. H., \& Hilman, H. (2018). Does organizational culture matter in the relationship between trust and SMEs performance. Management Decision. https://doi.org/10.1108/MD-05-2018-0557.

Grant, R. M. (1991). The resource-based theory of competitive advantage: Implications for strategy formulation. California Management Review, 33(3), 114-135.

Hafeez, M. H., Rizvi, S. M. H., Hasnain, A. \& Mariam, A. (2012). Relationship of leadership styles, employees commitment and organization performance (a study on customer support representatives). European Journal of Economics, Finance and Administrative Sciences, 1(49), 133-143.

Hair, J. F., Hult, G. T. M., Ringle, C., \& Sarstedt, M. (2013). A primer on partial least squares structural equation modeling (PLS-SEM). Thousand Oaks: Sage Publications.

Hair, J. F., Hult, G. T. M., Ringle, C., \& Sarstedt, M. (2014). A primer on partial least squares structural equation modeling (PLSSEM). Thousand Oaks: Sage publications.

Hair, J. F., Hult, G. T. M., Ringle, C., \& Sarstedt, M. (2016). A primer on partial least squares structural equation modeling (PLS-SEM). Thousand Oaks: Sage publications.

Hair, J. F., Hult, G. T. M., Ringle, C., \& Sarstedt, M. (2017). A primer on partial least squares structural equation modeling (PLS-SEM) (2nd ed.). Thousand Oaks: Sage Publications.

Hanifah, H., Halim, H. A., Ahmad, N. H., \& Vafaei-Zadeh, A. (2017). Innovation culture as a mediator between specific human capital and innovation performance among Bumiputera SMEs in Malaysia. In Handbook of research on small and medium enterprises in developing countries (pp. 261-279). Malaysia: IGI Global.

Hashim, M. K., Ahmad, S. A., \& Zakaria, M. (2012). A study on leadership styles in SMEs.

Hayduk, L. A., \& Littvay, L. (2012). Should researchers use single indicators, best indicators, or multiple indicators in structural equation models? BMC Medical Research Methodology, 12(1), 159.

Henri, J.-F. (2006). Management control systems and strategy: A resource-based perspective. Accounting, Organizations and Society, 31(6), 529-558.

Henseler, J., Ringle, C. M., \& Sinkovics, R. R. (2009). The use of partial least squares path modeling in international marketing. In New challenges to international marketing (pp. 277-319). Bingley: Emerald Group publishing limited.

House, R. J. (1998). Measures and assessments for the charismatic leadership approach: Scales, latent constructs, loadings, Cronbach alphas, and interclass correlations. Monographs in Organizational Behavior and Industrial Relations, 24, 23-30.

Hu, L.-T., \& Bentler, P. M. (1998). Fit indices in covariance structure modeling: Sensitivity to underparameterized model misspecification. Psychological Methods, 3(4), 424.

Hult, G. T. M. (1998). Managing the international strategic sourcing process as a market-driven organizational learning system. Decision Sciences, 29(1), 193-216.

Jansen, J. J., Vera, D., \& Crossan, M. (2009). Strategic leadership for exploration and exploitation: The moderating role of environmental dynamism. The Leadership Quarterly, 20(1), 5-18.

Jaramillo, F., Mulki, J. P., \& Marshall, G. W. (2005). A meta-analysis of the relationship between organizational commitment and salesperson job performance: 25 years of research. Journal of Business Research, 58(6), 705-714.

Jiménez-Jiménez, D., \& Sanz-Valle, R. (2011). Innovation, organizational learning, and performance. Journal of Business Research, 64(4), 408-417.

Keskes, I. (2014). Relationship between leadership styles and dimensions of employee organizational commitment: A critical review and discussion of future directions. Intangible Capital, 10(1), 26-51.

Kim, K., Watkins, K. E., \& Lu, Z. (2017). The impact of a learning organization on performance: Focusing on knowledge performance and financial performance. European Journal of Training and Development, 41(2), 177-193.

Kirkman, B. L., Chen, G., Farh, J.-L., Chen, Z. X., \& Lowe, K. B. (2009). Individual power distance orientation and follower reactions to transformational leaders: A cross-level, cross-cultural examination. Academy of Management Journal, 52(4), 744-764.

Klein, A. S., Wallis, J., \& Cooke, R. A. (2013). The impact of leadership styles on organizational culture and firm effectiveness: An empirical study. Journal of Management \& Organization, 19(3), 241-254.

Kotter, J. P. (1996). Leading change. Boston: Google Scholar.

Levine, K. J., Muenchen, R. A., \& Brooks, A. M. (2010). Measuring transformational and charismatic leadership: Why isn't charisma measured? Communication Monographs, 77(4), 576-591.

Liao, S.-H., Chen, C.-C., Hu, D.-C., Chung, Y.-C., \& Liu, C.-L. (2017). Assessing the influence of leadership style, organizational learning and organizational innovation. Leadership \& Organization Development Journal, 38(5), 590-609.

Lieberson, S., \& O'Connor, J. F. (1972). Leadership and organizational performance: A study of large corporations. American Sociological Review, 37(2), 117-130.

Makabila, G. P. (2018). Effect of organizational learning in achieving competitive advantage of state corporations in Kenya. Kenya: JKUAT-COHRED.

McClelland, D. C. (1975). Power: The inner experience. England: Irvington.

McGrath, R. G., Mac Grath, R. G., \& MacMillan, I. C. (2000). The entrepreneurial mindset: Strategies for continuously creating opportunity in an age of uncertainty (Vol. 284). Brighton: Harvard Business Press.

Megheirkouni, M. (2017). Leadership styles and organizational learning in UK for-profit and non-profit sports organizations. International Journal of Organizational Analysis, 25(4), 596-612.

Megheirkouni, M., Amaugo, A., \& Jallo, S. (2018). Transformational and transactional leadership and skills approach: Insights on stadium management. International Journal of Public Leadership, 14(4), 245-259.

Nafei, W. A. (2015). Organizational learning and organizational performance: A correlation study in the Kingdom of Saudi Arabia. American International Journal of Social Science, 4(2), 191-208. 
Nasir, W. M. N. B. W. M., Al Mamun, A., \& Breen, J. (2017). Strategic orientation and performance of SMEs in Malaysia. SAGE Open, 7(2), 2158244017712768.

Nazarian, A., Soares, A., \& Lottermoser, B. (2017). Inherited organizational performance? The perceptions of generation Y on the influence of leadership styles. Leadership \& Organization Development Journal, 38(8), 1078-1094.

Northouse, P. G. (2007). Leadership: Theory and practice. Washington D.C: Sage publications.

Podolny, J., Khurana, R., \& Hill-Popper, M. (2005). How to put meaning back into leading. In HBS Working Knowledge.

Podsakoff, P. M., Bommer, W. H., Podsakoff, N. P., \& MacKenzie, S. B. (2006). Relationships between leader reward and punishment behavior and subordinate attitudes, perceptions, and behaviors: A meta-analytic review of existing and new research. Organizational Behavior and Human Decision Processes, 99(2), 113-142.

Podsakoff, P. M., MacKenzie, S. B., Moorman, R. H., \& Fetter, R. (1990). Transformational leader behaviors and their effects on followers' trust in leader, satisfaction, and organizational citizenship behaviors. The Leadership Quarterly, 1(2), 107-142.

Podsakoff, P. M., Todor, W. D., Grover, R. A., \& Huber, V. L. (1984). Situational moderators of leader reward and punishment behaviors: Fact or fiction? Organizational Behavior and Human Performance, 34(1), 21-63.

Puffer, S., Porthouse, J., Birks, Y., Morton, V., \& Torgerson, D. (2004). Increasing response rates to postal questionnaires: A randomised trial of variations in design. Journal of Health Services Research \& Policy, 9(4), 213-217.

Rafferty, A. E., \& Griffin, M. A. (2004). Dimensions of transformational leadership: Conceptual and empirical extensions. The Leadership Quarterly, 15(3), 329-354.

Rahim, H. L., Zainal Abidin, Z., Mohtar, S., \& Ramli, A. (2015). The effect of entrepreneurial leadership towards organizational performance. International Academic Research Journal of Business and Technology, $1(2)$.

Rahim, R. A., Nik Mahmood, N. H., \& Masrom, M. (2016). Enhancing Malaysian's SMEs performance: Leadership and innovation. Advanced Science Letters, 22(5-6), 1530-1534.

Rehman, S.-U., Mohamed, R., \& Ayoup, H. (2019). The mediating role of organizational capabilities between organizational performance and its determinants. Journal of Global Entrepreneurship Research, 9(1), 30. https://doi.org/10.1186/s40497-019-0155-5.

Riaz, T., Ramzan, M., Ishaq, H. M., Akram, M. U., \& Karim, Y. (2012). Transformational leadership and employees career salience; an empirical study conducted on banks of Pakistan. International Journal of Business and Social Science, 3(8), 152-160.

Rothfelder, K., Ottenbacher, M. C., \& Harrington, R. J. (2012). The impact of transformational, transactional and non-leadership styles on employee job satisfaction in the German hospitality industry. Tourism and Hospitality Research, 12(4), 201-214.

Sanzo, M. J., Santos, M. L., García, N., \& Trespalacios, J. A. (2012). Trust as a moderator of the relationship between organizational learning and marketing capabilities: Evidence from Spanish SMEs. International Small Business Journal, 30(6), 700-726.

Sarti, D. (2014). Leadership styles to engage employees: Evidence from human service organizations in Italy. Journal of Workplace Learning, 26(3/4), 202-216.

Schein, E. H. (1992). Organizational culture and leadership (Vol. 2). New York: Wiley.

Schein, E. H. (2010). Organizational culture and leadership (5th ed.). New York: Wiley.

Sekaran, U., \& Bougie, R. (2016). Research methods for business: A skill building approach. New York: Wiley.

Shurafa, R., \& Mohamed, R. B. (2016). Management control system, organizational learning, and firm's performance: An empirical study from developing economy. International Journal of Advanced and Applied Sciences, 3(10), 79-88.

SMEinfo. (2018). Here's why SME matters in Malaysia. Retrieved August 23, 2018. from https://smeinfo.com.my/profile-of-smes.

Smith, M. J., Figgins, S. G., Jewiss, M., \& Kearney, P. E. (2018). Investigating inspirational leader communication in an elite team sport context. International Journal of Sports Science \& Coaching, 13(2), 213-224.

Stone, M. (1974). Cross-validatory choice and assessment of statistical predictions. Journal of the royal statistical society. Series $B$ (Methodological), 36(2), 111-133.

Sun, P. Y., \& Anderson, M. H. (2012). The combined influence of top and middle management leadership styles on absorptive capacity. Management Learning, 43(1), 25-51.

Teeratansirikool, L., Siengthai, S., Badir, Y., \& Charoenngam, C. (2013). Competitive strategies and firm performance: The mediating role of performance measurement. International Journal of Productivity and Performance Management, 62(2), 168-184.

Theodore, J. (2013). Absence of transformational leadership in Greek enterprises results in the inability of forming learning organizations. The International Business \& Economics Research Journal (Online), 12(6), 701.

Tourish, D. (2014). Leadership, more or less? A processual, communication perspective on the role of agency in leadership theory. Leadership, 10(1), 79-98.

Vera, D., \& Crossan, M. (2004). Strategic leadership and organizational learning. Academy of Management Review, 29(2), 222-240,

Verčič, A. T., \& Verčič, D. (2011). Generic charisma-conceptualization and measurement. Public Relations Review, 37(1), 12-19.

Wallach, E. J. (1983). Individuals and organizations: The cultural match. Training \& Development Journal, 37(2), 28-36.

Wang, F.-J., Chich-Jen, S., \& Mei-Ling, T. (2010). Effect of leadership style on organizational performance as viewed from human resource management strategy. African Journal of Business Management, 4(18), 3924-3936.

Wei, Y., O'Neill, H., Lee, R. P., \& Zhou, N. (2013). The impact of innovative culture on individual employees: The moderating role of market information sharing. Journal of Product Innovation Management, 30(5), 1027-1041.

Wernerfelt, B. (1989). From critical resources to corporate strategy. Journal of General Management, 14(3), 4-12.

Windsor, K. (2009). Correlation of nurse leadership style to organizational commitment of foreign-educated nurses in US hospitals. Phoenix: University of Phoenix.

Xenikou, A., \& Simosi, M. (2006). Organizational culture and transformational leadership as predictors of business unit performance. Journal of Managerial Psychology, 21(6), 566-579.

Yahaya, R., \& Ebrahim, F. (2016). Leadership styles and organizational commitment: Literature review. Journal of Management Development, 35(2), 190-216.

Yaslioglu, M. M., \& Erden, N. S. (2018). Transformational leaders in action: Theory has been there, but what about practice? IUP Journal of Business Strategy, 15(1), 42-53.

Yoshino, N., Taghizadeh-Hesary, F., Charoensivakorn, P., \& Niraula, B. (2016). Small and medium-sized enterprise (SME) credit risk analysis using bank lending data: An analysis of Thai SMEs. Journal of Comparative Asian Development, 15(3), 383-406.

Zhou, T. (2013). Understanding continuance usage of mobile sites. Industrial Management \& Data Systems, 113(9), 1286-1299. 